\title{
Mahalnya Pembiayaan di Bank Syariah
}

\author{
Sujian Suretno', Rivai Yusuf ${ }^{2}$ \\ ${ }^{1,2}$ STAI Al-Hidayah Bogor \\ sujiansuretno80@gmail.com
}

\begin{abstract}
This study provides a comprehensive picture of the public's perception of the high cost of financing Islamic banks in Indonesia. The perception of "expensive" arises from various perspectives based on the limited knowledge of each customer. In this study, the authors present explanations sourced from Islamic banks and several observers of Islamic banks in Indonesia. Primary data was obtained by conducting in-depth interviews with several Islamic bank practitioners, observations, and documentation studies. The data analysis technique uses the theory of Miles and Huberman, starting from data classification, data reduction, and drawing conclusions. The results of the study found several arguments which then formed the public perception that financing in Islamic banks was considered expensive. The word "expensive" here of course must be understood by defining the correct, authentic meaning, not with a misleading logical approach.

Keyword: islamic bank, financing, expensive, expensive perception.
\end{abstract}

\begin{abstract}
ABSTRAK
Penelitian ini memberikan gambaran yang komprehensif mengenai persepsi publik tentang mahalnya pembiayaan pada bank syariah di Indonesia. Persepsi "mahal" muncul dengan beragam sudut pandang yang didasarkan pada keterbatasan pengetahuan masing-masing nasabah. Dalam penelitian ini penulis menyajikan penjelasan yang bersumber dari pihak bank syariah dan beberapa pengamat bank syariah di Indonesia. Data primer diperoleh dengan melakukan wawancara mendalam dengan beberapa praktisi bank syariah, observasi, dan studi dokumentasi. Teknik analisis data menggunakan teori Miles and Huberman, dengan tiga tahapan; klasifikasi data, reduksi data, dan penarikan kesimpulan. Hasil penelitian menemukan beberapa argumentasi yang kemudian membentuk persepsi publik bahwa pembiayaan di bank syariah dianggap mahal. Kata "mahal" di sini tentu harus dipahami dengan pendefinisian makna yang benar, otentik, bukan dengan pendekatan logika yang menyesatkan.
\end{abstract}

Keyword: bank syariah, pembiayaan, mahal, persepsi mahal. 


\section{A. PENDAHULUAN}

Isu tentang mahalnya pembiayaan pada bank syariah di Indonesia masih hangat diperbincangkan oleh masyarakat, dunia akademik, dan praktisi. Mahalnya pembiayaan di bank syariah secara tidak langsung dapat menurunkan minat masyarakat untuk mengajukan pembiayaan di bank syariah. Pembiayaan konsumtif dan produktif akhirnya sulit diakses oleh masyarakat dan pelaku usaha mikro dan kecil. Buntunya solusi tersebut mengakibatkan mereka kembali atau memilih bank konvensional yang dipandang dapat memberikan kredit lebih murah, dan proses kredit yang lebih mudah. Apabila hal ini yang terjadi, maka bank-bank syariah di Indonesia akan sulit berkembang. Perbankan syariah di Indonesia harus terus didorong untuk dapat memberikan pembiayaan yang murah kepada masyarakat Indonesia agar terhindar dari riba, ghoror dan maisir.

Seberapapun mahalnya pembiayaan di bank syariah, bank syariah harus menjadi pilihan utama bagi umat Islam. Masalah prinsip pada penelitian ini adalah bagaimana bank syariah dapat memberikan penjelasan yang komprehensif kepada masyarakat tentang persepsi mahalnya pembiayaan. Harapannya adalah masyarakat puas dengan penjelasan tersebut, mengerti dengan kondisi bank syariah yang terus tumbuh dan berkembang, dan yang terpenting lagi mereka tetap loyal dengan bank syariah. Ada persepsi yang terbangun dari kata "mahal", mahal yang dimaksud apakah sedikit lebih mahal, ataukah terlalu mahal. Hal ini harus dibuktikan secara realitasnya. Mahal dalam arti lebih mahal pada harga suatu barang adalah hal yang biasa, yang menunjukkan ada persaingan pasar. Mahal dalam hal ini dapat dimaknai kompetitif. Lebih mahal tapi tetap terjangkau oleh masyarakat. Jadi mahal atau sedikit lebih mahal di sini masih di pandang wajar.

Kemudian makna yang kedua mahal dalam arti terlalu mahal, maknanya bahwa suatu barang tersebut posisinya pricingnya di atas harga pasar tentu ini yang kemudian dianggap tidak wajar. Oleh karena itu yang perlu diketahui dengan jelas adalah apakah yang dimaksud oleh publik adalah bahwa pembiayaan di bank syariah sedikit lebih mahal atau jauh lebih mahal apabila dibandingkan dengan bank konvensional. Walaupun secara umum masyarakat juga bisa menafsirkan sendiri, sebab kondisi saat ini bank syariah terus tumbuh dan berkembang, indikasinya adalah minat nasabah sangat tinggi terhadap bank syariah, baik dalam menabung atau deposito maupun dalam pembiayaan, baik pembiayaan yang bersifat produktif 
maupun konsumtif. Tulisan ini berupaya mengkonfirmasi pihak bank syariah apakah pembiayaan sedikit lebih mahal, jauh lebih mahal, atau bahkan setara dengan bank konvensional.

\section{B. TINJAUAN PUSTAKA}

Mahalnya pembiayaan pada bank syariah di Indonesia harus dipahami secara komprehensif. Seperti pada umumnya produk-produk yang laku dijual dipasaran biasanya memiliki beberapa karakteristik, di antaranya adalah karena produk tersebut murah sehingga dapat dijangkau oleh masyarakat dalam skala luas, kemudian barang tersebut berkualitas, manfaatnya dapat dirasakan dan diakui oleh pembeli, barang tersebut merupakan kebutuhan pokok seperti sembako, BBM, dan lain sebagainya. Produk-produk tersebut tentu jenisnya bermacam-macam, ada produk fisik berupa barang, produk jasa berupa jasa, dan produk digital.

Pada penelitian ini produk yang dibahas adalah produk jasa keuangan yaitu produk-produk pembiayaan pada bank syariah. Produk pembiayaan pada bank syariah memiliki karakteristik tertentu yang harus dipahami secara utuh. Pembiayaan adalah penyediaan dana atau tagihan yang dipersamakan dengan itu berupa transaksi bagi hasil dalam bentuk mudharabah dan musyarakah, transaksi sewa-menyewa dalam bentuk ijarah atau sewa beli dalam bentuk ijarah muntahiya bittamlik, transaksi jual beli dalam bentuk piutang murabahah, salam dan istishna, transaksi pinjam-meminjam dalam bentuk piutang atau qardh, dan transaksi sewamenyewa dalam bentuk ijarah untuk transaksi multijasa. Sedangkan yang dimaksud dengan bank syariah adalah bank yang menyelenggarakan kegiatan usahanya berdasarkan prinsip-prinsip syariah.

Bank syariah memberikan fasilitas pembiayaan kepada masyarakat baik pembiayaan yang bersifat produktif dan konsumtif. Pembiayaan produktif dalam bentuk musyarkah atau mudharabah biasanya digunakan untuk project financing atau kepemilikan asset komersial, sedangkan pembiayaan konsumtif biasanya digunakan untuk kepemilikan rumah, kendaraan dan lainlain.

Istilah mahal dan murah pada produk pembiayaan bank syariah harus disepakati terlebih dahulu oleh semua pihak, baik bank syariah maupun nasabah. Dalam kamus besar bahasa Indonesia dijelaskan bahwa yang dimaksud dengan mahal adalah apabila harga tersebut di atas harga pasaran, dan yang dimaksud murah adalah apabila harga tersebut di bawah harga pasaran. Murah dan mahalnya suatu barang jika mengacu pada penjelesan ini 
maka tidak bisa dimaknai secara relative. Ada beberapa persepsi yang menjadi opini publik dalam mendefinisikan murah atau mahal, di antaranya barang disebut murah walaupun harganya mahal kalau calon pembelinya itu memiliki uang yang banyak untuk membelinya, maka jika logikanya demikian, tidak dapat disamakan antara harga mahal dan daya beli yang kuat, karena jual beli itu mengacu pada keumuman harga pasar dan perilaku pasar. Boleh jadi orang yang kaya tidak mau membeli barang yang murah karena ia merasa barang tersebut tidak layak untuknya.

Murah dan mahalnya suatu barang diukur berdasarkan teori supply and demand.

\section{METODE}

Tulisan ini adalah penelitian kualitatif deskriptif. Data primer dan skunder diperoleh dengan cara melakukan wawancara mendalam dengan beberapa praktisi dari bank syariah, dan beberapa praktisi ekonomi Islam serta beberapa nasabah. Kemudian penulis juga melakukan obeservasi di lapangan dan studi dokumentasi. Teknik analisis data menggunakan teori Miles and Huberman dengan tiga tahapan mulai dari kategorisasi data, reduksi data, dan penarikan kesimpulan. Penulis menggunakan pendekatan fenomenologi dan teori ekonomi Islam dalam membahas permasalah ini. Metode ini dirasa sangat tepat untuk memecahkan rumusan masalah penelitian.

\section{HASIL PEMBAHASAN}

\section{Isi Hasil dan Pembahasan}

Sebelum membahas tentang mahalnya pembiayaan bank syariah di Indonesia, terlebih dahulu perlunya memetakan jenis-jenis bank syariah yang ada di Indonesia. Ada beberapa jenis bank syariah di Indonesia yaitu Bank Umum Syariah (BUS), Unit Usaha Syariah (UUS), dan Bank Pembiayaan Rakyat Syariah (BPRS). Bank Umum Syariah adalah bank syariah yang sudah beroperasi secara mandiri seperti Bank Muamalat Indonesia, Bank Syariah Indonesia (BSI) yang sebelumnya kita kenal dengan BNI Syariah, BRI Syariah, dan Bank Mandiri Syariah, dan bank-bank syariah lainnya. Bank syariah yang dikategorikan sebagai Bank Umum Syariah adalah bank yang memiliki modal lebih besar ketimbang bank-bank syariah lainnya seperti UUS dan BPRS. Namun demikian modal intinya masih di bawah bank-bank konvensional seperti BRI, Mandiri, BCA, dan lain-lain.

Jumlah modal inti bank, jumlah asset, dan market share bank syariah di Indonesia masih sangat kecil. Market share bank syariah per Januari 2021 mencapai $6,55 \%$. Jika dibandingkan 
dengan bank konvensional prosentasinya 6,55\%: 93,45\%. Bank dengan market share $93,45 \%$ menunjukkan bahwa penghimpunan dana pihak ketiga cukup besar. Besarnya DPK mempengaruhi tingkat murahnya Bunga pada deposito dan kredit.

Berdasarkan indepth interview dengan beberapa praktisi perbankan syariah, dapat dijelaskan beberapa asumsi berikut ini:

\section{a. Informan Pertama}

"Ini relatif tidak bisa diambil kesimpulan seperti itu, ada juga margin atau bagi hasil bank syariah yang lebih rendah dibanding bank konven, Kalupun bank konven bisa lebih rendah, ada beberapa triknya sebagai berikut:

1) Biasanya bunga dibuat rendah di awal untuk beberapa waktu, namun setelah itu bunganya dinaikan dengan angka yang lebih besar termasuk untuk kompensasi atas bunga yang rendah sebelumnya

2) Cost of fund dari bank tersebut bisa rendah sehingga saat menentukan bunga kreditnya bisa lebih rendah, Cost of fund bisa rendah karena portofolio DPK nya mayoritas dari tabungan dan Giro yg kadang tidak diberikan bunga simpanan, sedangkan bank yg jualan pembiayaan mahal dikarenakan sumber dananya mayoritas berasal dana mahal yaitu deposito

3) Bank konven bisa dengan gampang merubah-rubah tingkat suku bunga sesuai kondisi pasar dimana nominal angsuran bisa berubah-rubah, sedangkan bank syariah saat akad harga jual sudah ditentukan dari awal dan berlaku sampai jatuh tempo pembiayaan dimana angsuran tidak boleh berubah, sehingga saat tingkat bunga pasar sedang rendah, angsuran di bank syariah terlihat jd lebih mahal."

\section{b. Informan kedua}

"Masa sih lebih mahal...sama aja sebenarnya, sebenarnya karena strategi pasar saja jadi syariah keliatan lbh mahal. Ini kalau fight to fightnya setara, Bank Umum Syariah dengan Bank Umum Konvensional, kalau yang tidak setara biasanya cost of leonable fund nya yg berbeda.

Atau dengan kata lain ROE (Return On Invesment)-nya kan bakal besar Bank Umum Konvensional, jadi terbalik biasanya Bank Umum Konvensional besar jual margin pembiayaan besar, fundingnya kecil sebaliknya bank syariah 
yang belum besar jual pembiayaan besar pendanaan kecil

kalau kita mau deposito pilih bank kecil, rate atau bagi hasil besar karena butuh modal dan mereka pasti akan jual pembiayaan besar, ini yg disebut cost of leonable fund jadi sesuai kemampuan, modal besar kan harus balikin besar DPK nya maka pembiayaan juga harus naik, kalau kecil rugi, makanya jadi mahal, kalau yang bermodal besar jual murah tak masalah.

Tapi kalau di negara lain mungkin berbeda karena tingkat market sharenya sudah besar, seperti Malaysia, syariah mereka besar market share nya

kita ini negara mayoritas Islam tapi market share kecil jadi kondisinya ya spt itu."

\section{c. Informan ketiga}

"Mengapa pricing bank syariah lebih mahal?
1) Karena rata-rata bank syariah modal intinya masih kecil

2) Penerapan akad murabahah yang flat membuat harga tetap sampai akhir perjanjian

3) Bank Umum Konvensional dana pihak ketiganya didominasi oleh tabungan sehingga biaya fundingnya kecil

4) Bank Umum Syariah dana pihak ketiganya didominasi oleh deposito, sehingga biaya fundingnya besar

5) Besarnya biaya funding mempengaruhi mahalnya pembiayaan pada suatu bank

6) Bank syariah belum ada yang di buku IV

7) Market share bank syariah masih kecil." 


\begin{tabular}{|c|c|c|c|c|c|c|c|c|c|}
\hline IERANGAN & BSM & BMII & BNIS & BFos & BIPWS & BMS & BCAS & BJES & BSB \\
\hline \multicolumn{10}{|l|}{ PORANI POSISI KEUANGAVI } \\
\hline nlah Aset & 98.00 & 57.00 & 41.00 & 37,90 & 12.04 & 7,30 & 7.06 & 674 & 6.30 \\
\hline Piutant Murabahah Istishna \& Qardh & $37, \infty$ & 15,00 & 18.50 & 11,73 & 7,10 & 3,80 & 1.68 & 3.20 & 1,46 \\
\hline Pembiavaan 6 ljarah & $24, \infty$ & 16,00 & 710 & 9.00 & - & 1.20 & 3.10 & 1.10 & 250 \\
\hline Investasi & 17,50 & 12,00 & 7.40 & 9.00 & 1.03 & $1, \infty$ & 0,83 & 0,10 & 0,10 \\
\hline Kas \& setara kas & 22,00 & 6.00 & 5.00 & 6.20 & 3.20 & 0,65 & 1.08 & 1.40 & 1.30 \\
\hline Axtap B lainnya & 7,50 & 8,00 & 3,00 & 197 & 0.71 & 0,65 & 0.37 & 0,94 & 0,94 \\
\hline Dlah Hutane & 90,00 & 53.00 & 36.80 & 32.88 & 5.05 & 6,10 & 5.80 & 5.89 & 5,42 \\
\hline Dans Svikah Tempores & 75,00 & 44,00 & 27,00 & 20,99 & 5,99 & 5.20 & 5.02 & 487 & 4.12 \\
\hline Wadiah & 12,50 & 6,00 & 8.80 & 8.60 & 1.60 & 0,40 & 0,60 & 0.37 & 2,00 \\
\hline Hutang is innys & 2.50 & 3.00 & 1.00 & 3.29 & 0.46 & 0.50 & 0.19 & 0.65 & 0,30 \\
\hline ntah Modal & 8,00 & 4.00 & 4.20 & 5.02 & 3,99 & 1.20 & 1.26 & 0.85 & 0.88 \\
\hline \multicolumn{10}{|l|}{ PORAN LABA RUGI } \\
\hline ndapatan Dana & 7,60 & 3.20 & 3,60 & 3,12 & 3,44 & 0,60 & 0,45 & 0.67 & 0,49 \\
\hline ban Dans & 2,50 & 2.20 & 1.00 & 1,30 & 0,36 & 0,25 & 0.27 & 0.30 & 0.19 \\
\hline ndapatan(Beban) Lainma & 1,10 & 0.75 & 0.61 & 0.52 & 0,33 & 0.20 & 0.06 & - & 0,05 \\
\hline ban Operasional & 5,90 & 1,70 & 1.58 & 1.20 & 1.79 & 0,50 & 0,13 & 0,36 & 0,23 \\
\hline \multirow[t]{2}{*}{$\Delta a$} & 0,80 & 0.05 & 0.41 & a.10 & 0.96 & 0.05 & 0.06 & 0.01 & 0.02 \\
\hline & \multicolumn{9}{|c|}{ Ratioratio } \\
\hline \multicolumn{10}{|l|}{ Ratio Beban Dans } \\
\hline Pendapatan Dana / Beban Dana x $100 \%$ & $34 \times$ & 690 & $28 \mathrm{~N}$ & $42 \mathrm{~N}$ & $10 \%$ & $42 *$ & $60 \mathrm{~N}$ & $45 \mathrm{~s}$ & $39 \%$ \\
\hline \multicolumn{10}{|l|}{ Ratio BOPO } \\
\hline Deban Operasionai / Total Pendopatan x I00 & 615 & 435 & S3S1 & $46 \mathrm{~N}$ & SEs] & 635] & $35 \$$ & $545]$ & 525 \\
\hline \multicolumn{10}{|l|}{ Ratio Return on Equity (ROE) } \\
\hline Labo / Moda I x 1005 & 1001 & $1 \mathbf{1 8}$ & $10 \mathrm{~s}$ & 2s & $24 \times 6$ & $4 \mathrm{~N}$ & 5S: & 15 & 25] \\
\hline
\end{tabular}

\section{d. Informan keempat}

"Sebenarnya pembiayaan di bank syariah untuk saat ini relatif kompetitif, apalagi untuk di Bank Syariah Indonesia (BSI). Di BSI bagi hasil pada deposito dan pembiayaan cukup kompetitif, karena setelah terjadi marger antara Bank Mandiri Syariah, Bank BRI Syariah, dan Bank BRI Syariah modal ini BSI menjadi besar. Pada awal Februari 2022 BSI akan masuk buku IV. Jika BSI sudah masuk buku IV itu berarti posisi BSI sudah setara dengan bank-bank konvensional yang ada."

Berdasarkan data dari empat informan di atas ada beberapa temuan yang dapat dianalisis, di antaranya adalah:
1) Bak konvensional memiliki skema bunga rendah pada awal-awal tahun pembiayaan

Bank konvensional memiliki kelebihan dalam menetapkan bunga lebih rendah pada kredit di awal-awal tahun, misalkan selama satu sampai dengan dua tahun skema bunganya dibuat rendah terlebih dahulu, kemudian setelah masuk ke tahun ketiga, dan beberapa tahun setelahnya skema bunganya dibuat naik secara bertahap, bertambah tahun maka bunganya semakin naik. Pada hakikatnya skema bunga seperti ini lebih menarik bagi nasabah, 
karena dengan bunga rendah di awal-awal tahun keuangan mereka sangat terbantu, nasabah tidak terbebani dengan bunga yang tinggi sehingga mereka bisa mengatur cashflownya. Untuk kredit yang bersifat konsumtif skema ini sangat membantu nasabah misalkan untuk membeli rumah, atau kendaraan, untuk kebutuhan yang bersifat produktif skema ini sangat membantu nasabah untuk meningkatkan dan mengembangkan usahanya, karena di awal-awal mereka hanya mengangsur utang dengan bunga yang rendah. Ketika angsuran bunga rendah tersebut masih berjalan maka mereka akan menaikkan profit usaha mereka, sehingga pada saat keuntungan yang didadapat sudah sesuai ekspektasi mereka dapat membayar angsuran dengan bunga yang lebih tinggi dari beberapa tahun sebelumnya.

Sebenarnya skema bunga rendah di awal-awal tahun ini apabila ditotalkan sampai akhir tenor hasilnya tetap saja mahal, tetapi masyarakat tidak mempedulikan masalah itu, bagi mereka pembiayaan murah itu telah dirasakan pada awal-awal tahun, seperti kepemilikan rumah misalkan, data menunjukkan masyarkaat lebih memilih bank konvensional untuk kredit rumah. Pada bank syariah hal tersebut sulit untuk diterapkan. Ada beberapa alasan yang tidak memungkinkan untuk menerapkan skema tersebut; 1) pembiayaan di bank syariah didominasi oleh akad Murabahah. Akad murabahah merupakan akad yang paling mudah dan paling aman digunakan pada pembiayaan bank syariah. Dimana pembiayaan jual beli dengan akad almurabahah ini bank syariah dan nasabah sama-sama sepakat untuk melakukan akad jual beli dengan objek atau barang tertentu kemudian ditentukan harga pokok (harga beli)nnya dan harga jualnya. Setelah harga jualnya sudah disepakati oleh kedua belah pihak maka bank syariah akan menentukan berapa angsuran utang murabahahnya perbulan. Angsuran utang murabahah bersifat tetap selama masa perjanjian. Hal inilah kemudian yang membentuk persepsi masyarakat bahwa pembiayaan di bank syariah terlihat dan terkesan awal. Kesan mahalnya pembiayaan bank syariah lebih 
menguat lagi apabila nasabah mengajukan pembiayaan pada bank-bank syariah yang levelnya masih kecil.

2) Cost of fund bank konvensional lebih rendah di bandingkan dengan bank syariah

Eksistensi bank konvensional yang rentang waktunya jauh lebih lama dari bank syariah bahkan dalam kurun puluhan tahun di Indonesia tentu memiliki nasabah yang juga jauh lebih banyak dari bank syariah. Jika market share bank syariah saat ini hanya mencapai $6,55 \%$ tentu nasabah bank konvensional mencapai $94,5 \%$, ini perbandingan yang sangat tidak seimbang. Apabila kita menghitung komposisi nasabah bank syariah antara penabung dan deposan pasti banyak penabung. Dominasi jumlah penabung yang lebih banyak membuat jumlah penghimpunan dana pihak ketiga bank konvensional sangat besar namun customer returnnya sangat rendah. Hal tersebut karena pada saat awal eksistensi bank syariah diuntungkan dengan kebijakan pemerintah yang mewajibkan PNS, TNI, Polri, karyawan BUMN menggunakan bank konvensional. Selain itu mayoritas masyarakat Indonesia pun menggunakan bank konvensional untuk tabungan. Pada prinsipnya fungsi rekening tabungan lebih banyak digunakan untuk lalulintas keuangan ketimbang untuk investasi. Oleh karena itu apabila dominasi jumlah penabung yang aktivitas rekeningnya hanya digunakan untuk lalu-lintas menyebabkan beban bunga yang harus diberikan kepada penabung sangat rendah. Yang lebih efektif lagi adalah cost of funding bank konvensional juga sangat efisien sehingga hal tersebut membuat liquiditas kinerja keuangan bank konvensional sangat bagus dan maksimal sehingga ketika bank tersebut menyalurkan kredit kepada masyararkat bunganya pun sangat rendah. Hal ini kemudian yang sulit disaingi oleh bank syariah.

3) Modal inti bank syariah masih kecil

Modal inti bank syariah masih sangat kecil. Untuk saat ini kemungkinan modal inti bank syariah yang paling besar hanya BSI (Bank Syariah Indonesia), karena modal bank tersebut adalah gabungan dari tiga bank syariah 
sebelum di-marger yaitu Bank BNI Syariah, Bank Mandiri Syariah dan Bank BRI Syariah. Sedangkan bank-bank syariah yang lain modal intinya masih sangat kecil, apalagi modal dari Unit Usaha Syariah (UUS). Kondisi kecilnya modal inti bank syariah akhirnya membuat bank syariah menentukan kebijakan memberikan tingkat bagi hasil yang tinggi kepada deposan. Bank syariah yakin apabila bagi hasil yang diberikan kepada deposan lebih rendah dari Bunga yang diberikan kepada bank konvensional kepada deposannya maka hal tersebut menyebabkan para deposan akan mendepositokan uangnya ke bank syariah. Ketika bank syariah memberikan bagi hasil yang tinggi kepada deposan maka secara otomatis bank syariah akan meminta bagi hasil yang tinggi kepada nasabah yang melakukan pembiayaan.

Seperti yang kita ketahui bahwa dominasi pembiayaan di bank syariah adalah pada pembiayaan konsumtif. Itu artinya bank syariah lebih banyak memberikan pembiayaan kepada individuindividu masyarakat. Akhirnya nasabah yang mendapat pembiayaan dari bank syariah tersebut mereka dapat menyimpulkan bahwa di bank syariah bagi hasilnya mahal. Walaupun ada beberapa pembiayaan tertentu yang relative murah, seperti pembiayaan program kesejahteraan pegawai melalui kerjasama antara bank syariah dengan institusi baik itu perusahaan, koperasi, maupun lembaga pendidikan. Program kesejahteraan pegawai atau yang lebih dikenal dengan kredit potong gaji bagi hasilnya sangat rendah apabila dibandingkan dengan pembiayaan reguler karena risiko pembiayaan tersebut sangat rendah. Apabila risiko pembiayaan rendah maka bagi hasinya juga murah, dan apabila pembiayaan tinggi bagi hasinya juga sangat tinggi karena semuanya didasarkan pada tingkat risikonya.

4) Karakteristik akad murabahah yang mempersepsikan pembiayaan di bank syariah menjadi mahal.

Pembiayaan jual beli yang menggunakan akad Al-Murabahah pada prinsipnya adalah akad utang piutang atau transaksi secara tidak tunai, dimana pembeli dalam hal 
ini adalah nasabah membeli suatu barang ke bank syariah dengan harga yang disepakati kemudian total utang tersebut dicicil perbulan dengan jumlah tetap sampai tenor perjanjian berakhir. Skema ini tentu tidak dapat dibandingkan dengan skema bunga kredit pada bank konvensional. Apabila skema ini dibandingkan dengan total utang kredit berbunga pada bank konvensional dengan total utang murabahah pada bank syariah tentu hasilnya sangat jauh. Bank konvensional jauh lebih murah dari bank syariah, sedangkan bank syariah jauh lebih mahal, terlebih lagi apabila suku bunga BI pada periode tertentu turun, maka cicilan utang kredit bank konvensional juga ikut turun. Ini sesungguhnya persepsi yang harus diluruskan.

\section{Isi Hasil Pembahasan}

Sesungguhnya banyak sisi yang membuat pembahasan pada menelitian ini menjadi kompleks. Namun kerumitankerumitan tersebut paling tidak terjawab dari tabel di bawah ini:

\begin{tabular}{|l|l|l|l|}
\hline No & $\begin{array}{l}\text { Indikator yang } \\
\text { Mempengaruhi }\end{array}$ & Bank Konvensional & Bank Syariah \\
\hline 1 & Modal inti bank & Lebih besar & Lebih kecil \\
\hline 2 & Dana Pihak Ketiga (DPK) & Lebih besar & Lebih kecil \\
\hline 3 & Komposisi DPK & $\begin{array}{l}\text { Didominasi } \\
\text { tabungan }\end{array}$ & Didominasi deposito \\
\hline 4 & Cost of Fund & Lebih rendah & Lebih tinggi \\
\hline 5 & Customer Return & Lebih rendah & Lebih tinggi \\
\hline 6 & Market Share & $94,5 \%$ & $6,5 \%$ \\
\hline 7 & Model Angsuran & fleksibel & Tetap \\
\hline 8 & Distribusi Pembiayaan & Produktif & Konsumtif \\
\hline 9 & Jenis Pembiayaan & Halal dan Non Halal & Halal \\
\hline
\end{tabular}

Berdasarkan data di atas menunjukkan bahwa pembiayaan pada bank syariah lebih mahal jika dibandingkan dengan bank konvensional, namun demikian mahalnya pembiayaan di bank syariah masih kompetitif dan relative terjangkau. Hal tersebut dapat dibuktikan dengan banyaknya nasabah bank syariah. 
Artinya bank syariah sampai saat ini masih eksis. Industry tersebut walaupun lambat namun pasti tetap tumbuh dan berkembang di Indonesia. Hanya saja psikologi pasar yang tentu saja tidak mudah diintervensi oleh embel-embel syariah. Masyarakat tetap melihat bahwa selisih sedikit saja harga suatu barang akan dipersepsikan mahal, dan hal tersebut adalah sesuatu yang bersifat normal.

Mahalnya pembiayaan di bank syariah adalah fenomena yang riil terjadi. Data-data di atas cukup memberikan gambaran secara jelas indikator apa saja yang membuat pembiayaan di bank syariah menjadi mahal. Indikatorindikator tersebut dapat dijadikan sebagai parameter yang terukur untuk menilai tingkat mahalnya pembiayaan bank syariah, apabila masyarakat memahami secara utuh tentang data-data tersebut maka penulis yakin bahwa masyarakat akan mempersepsikan secara wajar. Wajar jika pembiayaan di bank syariah memang mahal, atau mahal dalam batas wajar. Perbandingan tingkat Bunga dan bagi hasil dalam pembiayaan dapat dibilang kompetitif, opininya mahal tapi tidak terlalu mahal, mahal tapi selisihnya tidak sampai dua kali lipat lebih mahal atatau $50 \%$ lebih mahal tidak. Lebih mahal hanya beberapa persen saja dan sifatnya relative dan berubah-ubah, mungkin bisa dibilang lebih malah $2 \%$ atau lebih mahal $3 \%$, tetap harus berdasarkan data yang valid.

Penulis berpendapat pembiayaan bank syariah tidak mengapa sedikit lebih mahal tetapi halal dan sesuai dengan prinsip-prinsip syariah yang mengandung keberkahan di dunia dan di akhirat. Substansinya kembali pada akad-akad syariah yang bebas dari riba, ghoror, dan maisir. Wallohu A'lam.

\section{E. KESIMPULAN}

Tulisan ini menyimpulkan bahwa pembiayaan di bank syariah lebih mahal apabila dibandingkan dengan bank konvensional. Ada 9 indikator yang menunjukkan hal tersebut, di antaranya; modal inti bank syariah lebih kecil, dana pihak ketiga bank syariah lebih kecil, kompoisi DPK didominasi oleh deposito yang menyebabkan bank syariah harus menggulirkan pembiayaan lebih mahal sehingga ROI-nya liquid, cost of fund bank syariah lebih tinggi, customer return bank syariah lebih tinggi, market share bank syariah masih kecil baru mencapai, 6,5\%, model angsuran di bank syariah tetap sampai akhir tenor pembiayaan, atau tidak mengikuti suku bunga, $80 \%$ pembiayaan bank syariah lebih ke sektor konsumtif, dan jenis pembiayaan bank syariah dibatasi hanya untuk sektor halal saja. Namun demikian jika pembiayaan di 
bank syariah itu lebih mahal, atau sedikit lebih mahal dari bank konvensional, maka hal tersebut dirasa wajar, karena parameternya sangat jelas. Mahalnya pembiayaan di bank syariah untuk saat ini juga masih terjangkau, hanya mahal beberapa persen saja. Walaupun pembiayaannya lebih mahal dari bank konvensional, namun kelebihan pembiayaan pada bank syariah adalah halal dan bebas dari unsur riba, ghoror, dan maisir.

\section{SARAN DAN UCAPAN \\ TERIMAKASIH}

Penulis yakin lambat laun industry perbankan syariah di Indonesia akan terus tumbuh dan berkembang sehingga dapat bersaing dengan bank-bank konvensional. Penulis berharap pemerintah dengan kebijakan makronya dapat mendukung meningkatnya market share bank syariah. Ucapan terimakasih disampaikan kepada Manajemen Proses Jurnal Ad-Deenar yang berkenan mempublish artikel ini. Semoga bermanfaat dan mencerahkan dunia akademik.

\section{DAFTAR PUSTAKA}

Rusydiana, Aam Slamet. (2016). Analisis Masalah Pengembangan Bank Syariah di Indonesia: Aplikasi Metode Analitic Network Process. Esensi: Jurnal Bisnis dan Manajemen, 6(2).
Ramly, Ar Royyan, Abdul Hakim. (2017). Pemodelan Efisiensi Bank di Indonesia: Perbandingan antara Bank Syariah dan Bank Konvensional. Esensi: Jurnal Bisnis dan Manajemen, 7(2).

Darma, Emile Satia, Rita Rita. (2011). Faktor-Faktor Yang Berpengaruh Terhadap Tingkat Pengguliran Dana Bank Syariah. Jurnal Akuntansi dan Investasi, 12(1).

Sarah, Sinta Rani Siti, Sumiyarti. (2016). Pengaruh Penyaluran Dana Bank Konvensional Dan Bank Syariah Terhadap Produk Domestik Bruto Di Indonesia. Jurnal Media Ekonomi, 24(2).

Adzimatinur, Fauziyah, Sri Hartoyo, Ranti Wiliasih. (2015). Faktor-Faktor yang Memengaruhi Besaran Pembiayaan Perbankan Syariah di Indonesia. Jurnal Al-Muzara'ah, 3(2).

Syafrida,Ida dan Indianik Aminah. (2015). Faktor Perlambatan Pertumbuhan Bank Syariah Di Indonesia Dan Upaya Penanganannya. Jurnal Ekonomi Dan Bisnis, 14(1): 7-20.

Fakhrina, Agus. (2015). Pengaruh Suku Bunga Kredit Dan Deposito Bank Konvensional Terhadap Margin Pembiayaan Murabahah Bank Syariah Di Indonesia. Jurnal Penelitian, 12(1): 39-54.

Hafidz MS., AM. M. (2015). Keterlekatan Sosial Inovasi Produk Bank Syariah di Indonesia. Jurnal Hukum Islam (JHI), 13(2): 70-78. 
Ad-Deenar: Jurnal Ekonomi dan Bisnis Islam, VOL: 5/NO: 02 DOI : 10.30868/ad.v5i02.1679
P-ISSN: 2356-1866

E-ISSN: 2614-8838 